\title{
STUDI KUALITATIF WAJIB PAJAK ORANG PRIBADI PENGUSAHA TERTENTU UNTUK MELAKUKAN PEMBAYARAN PAJAK PENGHASILAN (PPh) (Studi Kasus Pada Pelaku Social Commerce)
}

\author{
Dewita Puspawati \\ Program Studi Akuntansi, Fakultas Ekonomi dan Bisnis \\ Universitas Muhammadiyah Surakarta \\ dp123@ums.ac.id
}

\begin{abstract}
The purpose of this study was to determine the condition of knowledge of the perpetrators of social commerce as taxpayers specific employers to pay income tax on their business. The determination of the behavior of agents of social commerce when faced with the challenges to pay income tax, and how the constraints faced by the tax officer over tax collection social commerce transactions. This study is a qualitative study conducted by interviewing the perpetrators of social commerc. Interviews showed that the main factor of social commerce offender does not pay income tax is the lack of information if they are taxpayers and are required to pay taxes on the received income. They need have a clear criteria of social commerce taxation, payment term, and the certainty that they are not harmed. Various constraints faced by the tax office for tax purposes social commerce transactions also occur, such as the difficulty to track who transactors social commerce, difficulty to determine the tax object (to the digital format), transactions not only in the customs territory of Indonesia.
\end{abstract}

Keywords: Social Commerce, PPh, Wajib Pajak, WPOP Pengusaha Tertentu

\section{Pendahuluan}

Perkembangan Web 2.0 telah mengubah cara pengguna dan organisasi saling berinteraksi dan berkolaborasi. Meningkatnya penggunaan internet dan media sosial di Indonesia memberikan dampak yang besar bagi dunia bisnis. Meningkatnya popularitas situs jejaring sosial, seperti Facebook, Twitter, dan Instagram telah membuka kesempatan untuk membuka model bisnis baru dalam perdagangan elektronik, yang biasa disebut dengan social commerce (Liang dan Turban, 2011; Hajli, 2013; Jiang, et., al., 2014).

Adanya social commerce dapat dijadikan sasaran untuk mendapatkan wajib pajak potensial demi meningkatkan penerimaan pajak nasional. Tetapi, jumlah pelaku social commerce belum dapat dipastikan. Transaksi social commerce tidak jauh berbeda dengan transaksi konvensional, hanya saja platform yang digunakan adalah media sosial dengan fasilitas internet. Persentase aktivitas jejaring sosial Indonesia mencapai 79,72 persen yang merupakan tertinggi di Asia, mengalahkan Filipina (78 persen), Malaysia (72 persen), China (67 persen). Bahkan negara Asia dengan teknologi Internet maju, seperti
Korea Selatan dan Jepang pemanfaatan media sosialnya rendah, yaitu sebesar 30\% - $45 \%$ (merdeka.com, 2014).

Menurut Surat Peraturan Direktur Jenderal Pajak Nomor Per - 32/ PJ/ 2010, pelaku social commerce dikenakan pajak penghasilan pasal 25. Oleh karena kebanyakan pelaku social commerce adalah individu, maka dikategorikan sebagai Wajib Pajak Orang Pribadi Pengusaha Tertentu. Belum ada sosialisasi untuk pelaku social commerce mengenai pengenaan pajak penghasilan. Berbeda dengan transaksi electronic commerce telah diberikan Surat Edaran Direktur Jenderal Pajak Nomor SE-62/ PJ/ 2013 tentang Penegasan Ketentuan Perpajakan Atas Transaksi E-Commerce.

Sejak tahun 1983, perpajakan di Indonesia menganut Self Assesment System. Penerapan sistem ini akan efektif apabila kondisi kepatuhan sukarela (voluntary complience) pada masyarakat telah terbentuk (Mustikasari, 2007). Perubahan sistem pemungutan pajak menjadi Self Assesment System mengakibatkan wajib pajak diberikan kepercayaan sepenuhnya untuk menghitung, membayar, dan 
melaporkan sendiri pajak yang terutang berdasarkan ketentuan perundangan perpajakan, sedangkan fiskus berkewajiban melakukan pembinaan, pengawasan, dan pelayanan terhadap pemenuhan kewajiban perpajakan. Kelemahan self assessment system yang memberikan kepercayaan pada wajib pajak untuk menghitung, menyetorkan dan melaporkan sendiri pajak terutang, dalam praktiknya sulit berjalan sesuai dengan yang diharapkan atau bahkan disalahgunakan (Tarjo dan Kusumawati, 2006). Hal ini dapat didasari karena wajib pajak sengaja tidak patuh, rendahnya kesadaran untuk membayar pajak, atau kombinasi dari keduanya.

Belum diketahui apakah pelaku social commerce telah melakukan pembayaran pajak atas penghasilan yang diterima.

Direktorat Jenderal Pajak pun juga belum dapat mengawasi pelaksanaan pembayaran pajak pelaku social commerce, karena jumlah pelaku yang belum dapat dipastikan. Untuk pelaku social commerce kategori remaja, biasanya pengetahuan pajaknya lebih rendah, sehingga mereka kurang memperhatikan aspek perpajakan dari transaksi online. Bagi mereka, menjual barang melalui social commerce hanya pekerjaan sampingan yang tidak perlu dikenakan pajak. Untuk pelaku social commerce kategori dewasa seharusnya memiliki pengetahuan pajak yang lebih memadai, sehingga diharapakn kesadaran untuk membayar pajak lebih tinggi.

Berdasarkan latar belakang yang telah diuraikan, maka penelitian ini akan mengangkat beberapa masalah sebagai berikut:

1) Bagaimana kondisi pengetahuan pelaku social commerce (WP OP Pengusaha Tertentu) untuk melakukan pembayaran pajak penghasilan atas usahanya?

2) Bagaimana pelaku social commerce (WP OP Pengusaha Tertentu) akan menentukan perilakunya jika dihadapkan pada kondisi ia harus membayar pajak penghasilan?

3) Bagaimana kendala yang dihadapi kantor pajak atas pemungutan pajak transaksi social commerce?

\section{Kajian Pustaka}

\section{Theory of Reasoned Action (TRA)}

Theory of Reasoned Action (TRA) menawarkan penjelasan mengenai suatu perilaku atau tindakan (Ajzen and Fishbein, 1980; Fishbein and
Ajzen, 1975). TRA dijelaskan dengan adanya sikap dan norma subyektif yang dapat membentuk niat seseorang. Niat adalah kecenderungan seseorang untuk menggunakan sikap secara spesifik. Semakin kuat niat tersebut, maka semakin tinggi kemungkinan untuk melakukan suatu perilaku. Niat diyakini sebagai indikator yang baik untuk bertindak, tetapi tidak langsung mengarahkan pada tindakan nyata (Du, 2011).

Niat untuk berperilaku merupakan dipengaruhi oleh dua hal, yaitu sikap dan norma subjektif. Menurut Peslak, et.al. (2010), norma subjektif didefinisikan sebagai bagaimana sebuah perilaku dilihat dari lingkungan sosial seseorang, sehingga dapat mempengaruhi keputusannya. Sedangkan, sikap didefinisikan sebagai bagaimana perasaan seseorang mengenai perilakunya dan biasanya diukur berdasarkan mindset menyenangkan atau tidak menyenangkan (Peslak, et.al., 2010). Sehingga, niat dan norma subjektif akan mempengaruhi niat penjual melalui s-commerce untuk membayar pajak penghasilan, kemudian ia akan menentukan perilaku untuk membayar atau tidak membayar pajak penghasilan.

\section{Gambar 2.1 Model Theory of Reasoned}

\section{Action}

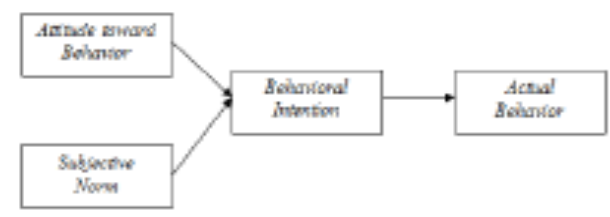

\section{Wajib Pajak Orang Pribadi Pengusaha Tertentu (WP OP Pengusaha Tertentu)}

Berdasarkan Pasal 1 Peraturan Direktur Jenderal Pajak Nomor Per - 32/ PJ/ 2010 tentang Pelaksanaan Pengenaan Pajak Penghasilan Pasal 25 Bagi Wajib Pajak Orang Pribadi Pengusaha Tertentu menjelaskan bahwa:

"Wajib Pajak Orang Pribadi Pengusaha

Tertentu adalah wajib Pajak orang pribadi yang melakukan kegiatan usaha sebagai Pedagang Pengecer yang mempunyai 1 (satu) atau lebih tempat usaha."

Pedagang pengecer yang dimaksud dijelaskan pada Pasal 2, yaitu orang yang melakukan penjualan barang baik secara grosir/ maupun eceran dan/ atau penyerahan jasa melalui suatu tempat usaha. Beberapa contoh yang termasuk wajib pajak orang pribadi 
pengusaha tertentu adalah pemilik salon, warnet, sewa kendaraan, kantor akuntan, praktik dokter, notaris, dan pengusaha online.

\section{Pajak Penghasilan (PPh 25) Atas WP OP Pengusaha Tertentu}

Pasal 2 ayat 1 Surat Peraturan Direktur Jenderal Pajak Nomor Per - 32/ PJ/ 2010 tentang Pelaksanaan Pengenaan Pajak Penghasilan Pasal 25 Bagi Wajib Pajak Orang Pribadi Pengusaha Tertentu mewajibkan wajib pajak orang pribadi pengusaha tertentu mendaftarkan diri untuk memperoleh Nomor Pokok Wajib Pajak bagi setiap tempat usaha di Kantor Pelayanan Pajak yang wilayah kerjanya meliputi tempat usaha tersebut dan di Kantor Pelayanan Pajak yang wilayah kerjanya meliputi tempat tinggal Wajib Pajak. Sesuai dengan pasal 3 ayat 1 Surat Peraturan Direktur Jenderal Pajak Nomor Per - 32/ PJ/ 2010 telah ditentukan besarnya angsuran pajak yang dikenakan pada wajib pajak orang pribadi pengusaha tertentu adalah $0,75 \%$ dari peredaran bruto setiap bulan dari masing-masing tempat usaha.

\section{Social Commerce}

Perkembangan situs jejaring sosial telah menciptakan paradigma perdagangan elektronik yang baru, yaitu social commerce (s-commerce). Marsden (2010) menjelaskan bahwa s-commerce merupakan kombinasi perdagangan elektronik dengan situs jejaring sosial untuk memfasilitasi pembelian dan penjualan produk dan jasa dengan menggunakan teknologi internet. S-commerce mengacu pada pengiriman aktivitas dan transaksi perdagangan elektronik melalui lingkungan media sosial, terutama dalam jejaring sosial yang menggunakan perangkat lunak Web 2.0 (Liang dan Turban, 2011). Shen dan Eder (2011) mendefinisikan s-commerce sebagai bentuk baru dari perdagangan elektronik dengan menggunakan media sosial, seperti media online yang mendukung interaksi dan kontribusi sosial untuk membantu pembelian dan penjualan produk dan jasa secara online.

Terdapat dua bentuk utama dari s-commerce. Pertama, jejaring sosial dapat menambahkan fitur yang memperbolehkan adanya iklan dan transaksi (Liang dan Turban, 2011). Kedua, perdagangan elektronik tradisional dapat menambah kemampuan mereka untuk membuat akun dalam jejaring sosial untuk mendapatkan keuntungan dari kekuatan media sosial (Liang dan Turban, 2011).

\section{Metode Penelitian}

Paper ini menggunakan dua metode pengumpulan data, yaitu:

1) Wawancara

Wawancara digunakan sebagai teknik pengumpulan data apabila peneliti ingin melakukan studi pendahuluan untuk menemukan masalah yang harus diteliti dan juga apabila peneliti ingin mengetahui hal-hal dari responden yang lebih mendalam dan jumlah respondennya sedikit/ kecil (Sugiyono, 2013). Wawancara dilakukan pada beberapa pelaku social commerce untuk mengetahui bagaimana kondisi pengetahuan mereka terhadap keharusan untuk membayar pajak penghasilan dan pendapat mereka jika harus membayar pajak penghasilan. Pelaku social commerce yang dimaksud adalah pemilik dari@rahmihdy, @sweaterrajut_shop, @ rosmi.os, @evts_tasikmalaya,dan@tasrajutda-lova.

\section{2) Teknik Dokumentasi}

Menurut Sugiyono (2013), dokumen merupakan catatan peristiwa yang sudah berlalu yang berbentuk tulisan, gambar, atau karya-karya monumental dari seseorang. Studi dokumen merupakan pelengkap dari penggunaan metode wawancara dalam paper ini. Dokumen yang digunakan adalah jurnal ilmiah, tulisan atau opini yang bersumber dari www.pajak.go.id, dan berita.

\section{Hasil dan Pembahasan}

\section{Analisis Deskriptif}

Sistem berbelanja online di Indonesia terbagi melalui tiga saluran. Pertama, lewat toko online, seperti lazada.com dan zalora.co.id. Kedua, melalui platform yang mempertemukan penjual dengan pembeli, sekaligus menjadi forum bagi keduanya, contohnya kaskus.co.id dan tokobagus.com. Ketiga, melalui jejaring sosial atau social commerce (Arianto, 2014). Pelaku social commerce merupakan subjek pajak Undang-Undang No. 36 Tahun 2008 tentang Pajak Penghasilan. Kewajiban untuk membayarkan pajak penghasilan ini timbul sejak saat orang pribadi atau badan tersebut menjalankan usaha atau melakukan kegiatan sehingga memperoleh penghasilan (Gade dan Gade, 1995). Pengenaan pajak jual beli untuk toko online pada dasarnya dipersamakan dengan toko konvensional sehingga ketentuan pajak yang berlaku bagi usaha online tidak berbeda dengan toko konvensional pada umumnya. Perbedaan yang 
mendasar hanya usaha online dilakukan dengan menggunakan fasilitas internet.

Sesuai dengan Peraturan Direktorat Jenderal Pajak Nomor PER-32/PJ/2010 tentang pelaksanaan pengenaan $\mathrm{PPh}$ pasal 25 bagi Wajib Pajak orang pribadi pengusaha tertentu, pengusaha social commerce dikenakan $\mathrm{PPh}$ sebesar $0,75 \%$ dari omzet setiap bulannya. Dengan berlakunya PP Nomor 46 tahun 2013, maka perlakuan pajak pengusaha ecommerce (termasuk social commerce) dengan peredaran bruto tidak melebihi Rp4,8 milliar dikenakan pajak sama dengan pajak UMKM, yaitu $1 \%$ dari omzet (Arianto, 2014).

\section{Pembahasan Masalah}

\section{Kondisi Pengetahuan Pelaku Social Commerce Untuk Membayar Pajak}

Peneliti melakukan wawancara dengan 5 orang responden untuk mencari tahu apakah pelaku social commerce mengetahui kondisi bahwa penghasilan yang mereka dapatkan harus dikenakan pajak. Beberapa hasil wawancara oleh para pelaku social commerce adalah sebagai berikut:

"Tidak tahu, karena saya tidak tahu informasi bahwa harus membayar pajak." (Narasumber I)

"Tidak, karena menurut saya bisnis online tidak perlu dikenakan pajak." (Narasumber II)

"Belum tahu, karena belum ada informasinya [pembayaran pajak]." (Narasumber IV)

Pelaku social commerce biasanya berumur remaja hingga dewasa. Tempat usaha social commerce adalah media sosial, bukan seperti toko konvensional, sehingga terdapat anggapan bahwa bisnis online tidak perlu membayar pajak. Faktor utama pelaku social commerce tidak membayar pajak penghasilan adalah kurangnya informasi jika mereka merupakan wajib pajak dan diharuskan membayar pajak atas penghasilan yang diterima. Pengetahuan Wajib Pajak tentang pajak yang baik akan dapat memperkecil adanya penghindaran pajak (Palil, 2005). Cristensen, et al. (1994) bahwa wajib pajak yang memiliki pengetahuan yang baik, akan memiliki persepsi keadilan yang positif terhadap sistem pajak yang berakibat tingkat kepatuhan pajak lebih tinggi. Pemerintah perlu mengadakan sosialisasi terhadap pemungutan pajak atas wajib pajak orang pribadi pengusaha tertentu, khususnya pengguna social commerce atau pebisnis online.

Perilaku Pelaku Social Commerce Jika Dihadapkan pada Kondisi Harus Membayar Pajak

Wawancara dilakukan untuk mengetahui bagaimana pelaku social commerce akan menentukan perilakunya jika dihadapkan pada kondisi mereka telah mengetahui informasi pengenaan pajak penghasilan social commerce. Hasil wawancara dari beberapa pelaku adalah sebagai berikut:

"Lihat kondisi penjual lain dan penghasilan yang saya dapatkan. Kalo sedikit [penghasilan] sih, saya lebih tidak peduli." (Narasumber I)

"Tidak bayar." (Narasumber II)

"Ikut aturan yang berlaku aja." (Narasumber

III)

"Mengikuti aturan dan membayar pajak." (Narasumber IV)

"Kalo misalnya dikenakan pajak bolehboleh saja, asal online shop kita diakui sebagai online shop yang trusted dan bukan penipuan." (Narasumber V)

Satu dari lima responden lebih memilih tidak bayar karena ia berpendapat bahwa bisnis online tidak perlu dikenakan pajak. Responden yang lain lebih melihat tergantung pada omset yang didapat. Tiga dari lima responden lebih memilih perilaku untuk membayar pajak dan mengikuti aturan yang telah ditetapkan, tetapi dengan syarat bahwa kredibilitas online shop-nya terjamin. Peningkatan kredibilitas online shop dapat meningkatkan penghasilan pelaku social commerce.

Beberapa responden juga menanggapi bahwa mereka perlu membayar pajak, yaitu sebagai berikut:

"Biaya pengiriman barang dan pulsa sudah menambah beban modal [usaha], sehingga saya tidak mau membayar pajak lagi. Apalagi biaya pengiriman barang kan sudah dikenakan pajak." (Narasumber II)

"Boleh aja dikenakan pajak, asal pajak itu tidak disalahgunakan dan jelas penggunaannya." (Narasumber III)

"Gak papa sih bisnis online dikenakan pajak, tapi harusnya ada feedback yang kita dapatkan dari pemerintah atas pembayaran pajak itu dan metode, serta tata cara 
pembayaran yang jelas, sehingga tidak merugikan para pelaku social commerce."

(Narasumber IV)

Pelaku social commerce perlu kejelasan kriteria pengenaan pajak, tata cara pembayaran, dan kepastian agar mereka tidak dirugikan. Salah satu responden menunjukkan keraguan penggunaan dana pajak oleh instansi pemerintah, sehingga mempengaruhi pola pikir serta perilakunya. Menurut Menurut Franzoni (1999), salah satu faktor yang mempengaruhi kepatuhan Wajib Pajak adalah kecenderungan mereka terhadap institusi publik. Pemerintah dan instansi pemungutan pajak harus menunjukkan sikap tidak memberatkan pelaku social commerce, sehingga terjalin kepercayaan antara pelaku dan aparat pajak.

\section{Kendala yang Dihadapi Instansi Pajak atas} Pemungutan Pajak Transaksi Social Commerce

Menurut Arianto (2014) ada banyak kendala

yang dihadapi untuk pengenaan pajak atas transaksi online, yaitu:

1) Transaksi e-commerce (termasuk social commerce) terjadi dalam waktu yang singkat, sehingga sangat sulit untuk melacak siapa saja pelaku transaksinya.

2) Jika bentuk barang atau jasa yang diperdagangkan berformat digital (nonfisik) seperti software, video, musik, e-magazine, sehingga cukup menyulitkan dalam penentuan obyek pajaknya.

3) Bukti transaksinya adalah bukti elektronis sehingga membuat transaksi e-commerce (termasuk social commerce) semakin susah untuk dideteksi.

4) Transaksi online tak hanya terjadi di dalam wilayah pabean Indonesia saja, namun terkadang menembus batas geografis negara lain.

Terdapat beberapa kendala lain untuk pengenaan pajak transaksi social commerce, yaitu:

1) Tidak ada jumlah yang pasti pelaku social commerce (penjual) pada berbagai macam media sosial, seperti Instagram, Path, Facebook, Twitter, Blackberry Messenger, sehingga Dirjen Pajak belum mengetahui jumlah wajib pajak potensial.

2) Adanya sistem reseller dan dropship, sehingga transaksi yang terjadi lebih sulit dideteksi.
Sistem reseller berarti penjual membeli barang dari penjual lain dengan harga yang lebih murah, kemudian ia menjual kembali barang tersebut baik sevara online ataupun offline. Sistem dropship dapat diilustrasikan, penjual I di kota Banding memiliki barang dagangan sweater, dan penjual II di kota Yogyakarta ingin menjual kembali sweater tersebut dengan margin yang lebih tinggi, tetapi penjual II tidak ingin memiliki persediaan barang sweater karena jika dikirimkan ke Yogyakarta akan dikenakan biaya kirim yang berakibat akan menaikkan biaya modal penjual II. Penjual II dapat menjual barang seolah-olah ia memiliki persediaan barang dagangan. Jika ada pembeli yang membeli di penjual II, maka penjual II akan memberitahukan penjual I, kemudian penjual I akan mengirimkan langsung barang dagangan ke pembeli.

3) Adanya sistem pembayaran cash on delivery (COD) yang transaksi uangnya susah ditelusuri. Untuk pembelian yang terjadi dalam satu kota, biasanya pembeli menggunakan sistem pembayaran COD dibandingkan transfer ATM karena ia dapat melihat barang asli yang ia beli, kemudian ia akan langsung membayarnya.

Salah satu langkah awal sebagai solusi yang dapat dilakukan Direktorat Jenderal Pajak adalah bekerja sama dengan perusahaan-perusahaan TI dan perbankan untuk mendeteksi transaksi online yang selama ini susah dilacak, dan mensosialisasikan pelaku social commerce bahwa terdapat kewajiban membayar pajak. Sarana teknologi informasi seperti software maupun hardware yang kurang memadai yang dimiliki pemerintah, menjadi salah satu penghambat pemungutan pajak transaksi elektronik (Arianto, 2014).

\section{Simpulan}

Belum diketahui apakah pelaku social commerce telah melakukan pembayaran pajak atas penghasilan yang diterima. Direktorat Jenderal Pajak pun juga belum dapat mengawasi pelaksanaan pembayaran pajak pelaku social commerce, karena jumlah pelaku yang belum dapat dipastikan. Hasil wawancara menunjukkan pengetahuan pelaku social commerce terhadap kewajiban membayar pajak masih rendah karena kurangnya informasi yang diterima. 
Wajib Pajak harus diperlakukan sebagai sebagai subyek yang harus dibina agar bersedia, mampu dan sadar melaksanakan kewajiban perpajakan (Sofyan, 2003).

Jika pelaku social commerce dikondisikan jika mereka sudah mengetahui kewajiban pembayaran pajak, mereka akan mengikuti aturan yang berlaku. Tetapi, ada pelaku yang beranggapan ia tidak ingin bayar dan melihat besarnya omset karena pembayaran pajak menjadi hal yang memberatkan usaha mereka. Pelaku social commerce menginginkan kejelasan metode dan tata cara yang jelas jika mereka diharuskan untuk membayar pajak.

Berbagai kendala yang dihadapi kantor pajak untuk pemungutan pajak transaksi social commerce juga terjadi, diantaranya sulitnya melacak siapa saja pelaku transaksi social commerce, sulit menentukan obyek pajaknya (untuk yang berformat digital), transaksinya tidak hanya dalam wilayah pabean Indonesia saja. Dalam cakupan yang lebih sempit, kendala yang dihadapi dalam proses pemungutan pajak transaksi social commerce adalah tidak ada jumlah yang pasti pelaku social commerce, adanya sistem reseller dan dropship, dan sistem pembayaran cash on delivery (COD).

\section{Daftar Pustaka}

[1] Ajzen, I. dan M. Fishbein. 1980. Understanding Attitudes and Predicting Social Behavior. Englewood Cliffs. NJ: Prentice-Hall.

[2] Arianto, Nur. 2014. Ekstensifikasi Pajak Dari Transaksi Online. Portal Kemenkeu. Diakses tanggal 8 September 2015.

[3] Du, Y. 2011. A Measurement Model of Students' Behavioral Intentions to Use Second Life Virtual Environments. Journal of Education for Library and Information Science, Vol. 52, No.1, pp. 4153.

[4] Franzoni, A. Luigi. 1999. Tax Evasion and Tax Compliance. Italy: University of Bologna.

[5] Fishbein, M. dan I. Ajzen. 1975. Belief, Attitude, Intention, and Behavior: An Introduction to Theory and Research. Addison-Wesley, Reading, Mass.

[6] Gade, Muhammad dan Djamaludin Gade. 1995. Hukum Pajak. Jakarta: LPFE-UI.

[7] Hajli, M. N. 2013. A Research Framework for Social Commerce Adoption. Information
Management and Compututer Security, Vol. 21, No. 3, pp. 144-154.

[8] Jiang, G., F. Ma, J. Shang, dan P. Y. K. Chau. 2014. Evolution of Knowledge Sharing Behavior in Social Commerce: An Agent-Based Computational Approach. Information Science, Vol. 278, pp. 250-266.

[9] Liang, T. P. dan W. Turban. 2011. Introduction to the Special Issue Social Commerce: A Research Framework for Social Commerce. International Journal of Electronic Commerce, Vol. 16, No. 2, pp. 5-13.

[10] Marsden, P. 2010. Social Commerce: Monetizing Social Media. Syzygy Group.

[11] Merdeka. 2013. Di 5 Media Sosial Ini, Orang Indonesia Pengguna Terbesar Sedunia. http://www.merdeka.com/uang/di-5-media-sosialini-orang-indonesia-pengguna-terbesardunia.html. Diakses tanggal 8 September 2015.

[12] Mustikasari, Elia. 2007. Kajian Empiris Tentang Kepatuhan Wajib Pajak Badan Di Perusahaan Industri Pengolahan Di Surabaya. Simposium Nasional Akuntansi X.

[13] Palil, M Rizal. 2005. Does Tax Knowledge Matter in Self Assessment System? Evidence from Malaysia Tax Administrative. The Journal of American Academy of Business. Cambrige. No. 2.

[14] Peslak, A., W. Cecucci, dan P. Sendall. 2010. An Empirical Study of Instant Messaging (IM) Behavior Using Theory of Reasoned Action. Institute of Behavioral and Applied Management, pp. 263-278.

[15] Republik Indonesia. 2010. Peraturan Direktorat Jenderal Pajak Nomor PER-32/PJ/2010 Tentang Pelaksanaan Pengenaan Pajak Penghasilan Pasal 25 Bagi Wajib Pajak Orang Pribadi Pengusaha Tertentu. Jakara: Direktorat Jenderal Pajak.

[16] Republik Indonesia. 2013. Peraturan Pemerintah Republik Indonesia Nomor 46 Tentang Pajak Penghasilan Atas Penghasilan Dari Usaha Yang Diterima Atau Diperoleh Wajib Pajak Yang Memiliki Peredaran Bruto Tertentu. Jakarta: Direktorat Jenderal Pajak.

[17] Shen, J. dan L. Eder. 2011. An Examination of Factors Associated with User Acceptance of Social Shopping Websites. International Journal of Technology and Human Interaction, Vol. 7, No. 1, pp. 19-36. 
[18] Sofyan, S. 2003. Sistem Penetapan Pajak (Dalam Kerangka Mencari Sistem Yang Kondusif). Jurnal Perpajakan Indonesia. Vol 3, hal 28-34.

[19] Sugiyono. 2013. Metode Penelitian Kuantitatif, Kualitatif, dan R\&D: Cetakan Ke-19. Bandung: Alfabeta CV.

[20] Tarjo dan Indra Kusumawati. 2006. Analisis Perilaku Wajib Pajak Orang Pribadi Terhadap Pelaksanaan Self Asessment System: Suatu Studi di Bangkalan. JAAI, Vol. 10, No. 1, hal. 101-120. 